\title{
To What Extent Are Swiss Springs Refugial Habitats for Sensitive and Endangered Diatom Taxa?
}

\author{
Lukas Taxböck $^{1, *}$, Hans Peter Linder ${ }^{1}$ and Marco Cantonati ${ }^{2}$ \\ 1 Department of Systematic and Evolutionary Botany, University of Zurich, Zollikerstrasse 107, 8008 Zurich, \\ Switzerland; peter.linder@systbot.uzh.ch \\ 2 Museo delle Scienze-MUSE, Limnology and Phycology Section, Corso del Lavoro e della Scienza 3, \\ 38123 Trento, Italy; marco.cantonati@muse.it \\ * Correspondence: lukas.taxboeck@systbot.uzh.ch
}

Received: 30 September 2017; Accepted: 9 December 2017; Published: 12 December 2017

\begin{abstract}
Habitat alteration is one of the major drivers of species loss. Springs may be among the least affected aquatic habitats and are considered to be refugial habitats. Diatom assemblages were sampled from 74 Swiss springs comprising seven spring types over a wide altitudinal and ecological range as well as a wide range of anthropogenic modifications (alterations). Each spring was assigned to a five-point alteration scale, from natural to heavily altered. In total, 504 diatom species were recorded (not including 36 taxa that could not be identified to species level) from five microhabitats, and coded according to rarity and Red List status. The results of this extensive spring-habitat diatom survey were compared statistically with a large stream diatom dataset (DI-CH). The spring diatom microflora was more species rich and included more rare and/or threatened species than the stream microflora. The proportion of Red List species and rare species was highest in the DI-CH dataset, but the proportion of species with no Red List status and rare species was the highest in springs. Species richness, Red List status, and rarity were significantly related to the degree of spring alteration. This is consistent with the hypothesis that unaltered springs function as refuges for the Swiss fresh water microflora, and that they can be regarded as "least-impaired habitats". These may be critically important for the conservation of the European freshwater diatom microflora.
\end{abstract}

Keywords: groundwater; stream; biodiversity; ecological status; conservation evaluation; algae

\section{Introduction}

Globally, the aquatic biota has been much more affected by human impact than the terrestrial biota [1], and this also applies to Switzerland [2]. Although freshwater habitats occupy less than $1 \%$ of the earth's surface, they host approximately $10 \%$ of all known species [3]. Springs may be the most pristine remaining aquatic habitats [4]. Near-natural springs often host on a small spatial scale a high species richness [4], offering a range of microhabitats for many organisms, such as invertebrates [5], macrophytes [6], and diatoms [7]. Springs are often little impacted by anthropogenic disturbances and are stable habitats because of the environmental conditions of the spring-feeding aquifer [8]. Springs vary considerably in habitat diversity and physical and chemical variables. Scientific interest in spring habitats has increased in the last two decades, and in particular, diatoms in springs have received much attention in some European countries [9-12]. These studies showed that springs are species rich habitats with relatively high proportions of rare and threatened diatom species. They also led to the discovery of new diatom species and genera [4,13-15], as well as new taxa from other groups of organisms; e.g., Gerecke [16] described a new subgenus of water mites from a hygropetric spring. Many of these new species are rare or crenophilous (i.e., occurring preferentially in springs and comparable habitats). Springs have also been shown generally to be refugial habitats, for example as shelter from flood events or desiccation, as nurseries, as last fragments of high-quality freshwater 
habitats in an impacted landscape (see Cantonati et al. [17] for a review), or as mid-continent saline helocrenes that may host marine species [18].

The most threatened freshwater ecosystems are near-natural springs in densely populated agricultural areas [17]. Studies on pristine alpine environments [19] refer to mountain springs as sources for diatom biodiversity and niches for rare species. Some species survive only in densely populated and intensively exploited areas in springs not affected by humans. Botosaneanu [20] referred to these as "geographic relict" species. However, the term geographic relict can lead to some confusion, e.g., with glacial or Tertiary relicts. Consequently, Cantonati et al. [4] proposed the term least-impaired habitat relicts (LIHRe) to characterize organisms persisting in springs retaining a near-natural character despite their location in densely populated regions [4].

The Baas Becking [21] postulate, everything is everywhere, but environment selects, dominated biogeographical thinking for unicellular organisms. However, despite some results supporting the Baas Becking postulate [22-24], a growing number of studies indicate biogeographical patterns for microorganisms [25-27]. Species with limited dispersal can become vulnerable when their habitat changes. Vyverman et al. [27] showed for diatoms in lakes worldwide not only a significant correlation between the regional species pool and the diversity of local communities, but also the influence of habitat availability on regional and local species richness. Consequently, the conservation of regional refugial habitats is critical for the survival of freshwater species, lending an urgency to the recognition of local least-impaired habitats.

Here, we compare a comprehensive, taxonomically accurate, and updated survey of the diatom microflora of the diverse microhabitats (i.e., substrates) in 74 springs with a large stream-diatom dataset (DI-CH) to test if unaltered springs can be regarded as Least-Impaired Habitats and can thus function as refuges for the Swiss freshwater diatom microflora. In pursuing this general objective, we asked the following specific research questions: (a) are springs more species-rich than streams; (b) are endangered species lost more rapidly than common and widespread ones when springs are disturbed; (c) do all substrates generally host similar fractions of endangered Red List species; and (d) can anthropogenically unaltered spring habitats be refugia for sensitive and endangered diatom species, because (1) species that are rare in running waters are more frequent in near-natural springs; and (2) these species become less frequent in springs with an increasing degree of alteration.

\section{Materials and Methods}

\subsection{Sampling and Laboratory Methods}

We sampled 74 springs in central and eastern Switzerland as well as the Jura Mountains (Figure 1). Every spring was sampled once in the summer months between 2009 and 2011. The sampled springs belong to seven spring types: flowing springs (rheocrenes) $(N=31)$, seepage springs on steep slopes (rheohelocrenes) $(N=7)$, seepage springs (helocrenes) $(N=16)$, pool springs (limnocrenes) $(N=1)$, seepage springs with a variable outflow, e.g., precipitation dependent (linear springs) $(N=1)$, rockface seeps (hygropetric springs) $(N=2)$, and distinctly altered springs, e.g., for water withdrawal (walled springs) $(N=6)$.

The sampling area in rheocrenes and rheohelocrenes was delimited by the lower eucrenal (i.e., springhead) where bryophyte cushions stopped growing. In helocrenes and hygropetric and linear springs, sampling was empirically delimited as the distance from the outflow of 3 to 5 times the spring mouth diameter. Limnocrenes were delimited by the pool size, and walled springs were sampled as close as possible to the outflow. To cover the springs' heterogeneous habitat diversity, up to five different microhabitats were sampled from different points within the spring: stones, surface sediment, bryophytes, filamentous green-algae, and leaf litter. Sampling of stones was conducted by brushing the benthic diatom cover from 5 to 10 cobbles or small boulders in each spring. If only small gravel $(\varnothing<2 \mathrm{~cm})$ was available, $10-15$ small stones were sampled as a whole. Surface sediment often accumulates in still water areas within the spring perimeter and consists mainly of sand, silt, 
and organic detritus. With one way pipettes, approximately $10-20 \mathrm{~cm}^{3}$ of sediment was aspired from the surface. From bryophytes, filamentous green-algae, and leaf litter, $30-40 \mathrm{~cm}^{3}$ of their submersed parts were taken. The samples from each of these substrates were preserved separately.

The samples were preserved and stored in $4 \%$ formaldehyde solution. Frustules were cleaned with standard methods according to Hürlimann et al. [28]. First, the samples were cleaned with hydrochloric acid to dissolve calcareous compounds and coarse particles were filtered out with a mesh sieve (mesh ø $1 \mathrm{~mm}$ ). Then, the frustules were cleaned in concentrated sulphuric acid and potassium nitrate, and repeatedly washed with deionised water until the $\mathrm{pH}$ reached $\geq 6$. Finally, the cleaned frustules were mounted on permanent slides with Naphrax (refractive index $=1.74$ ).

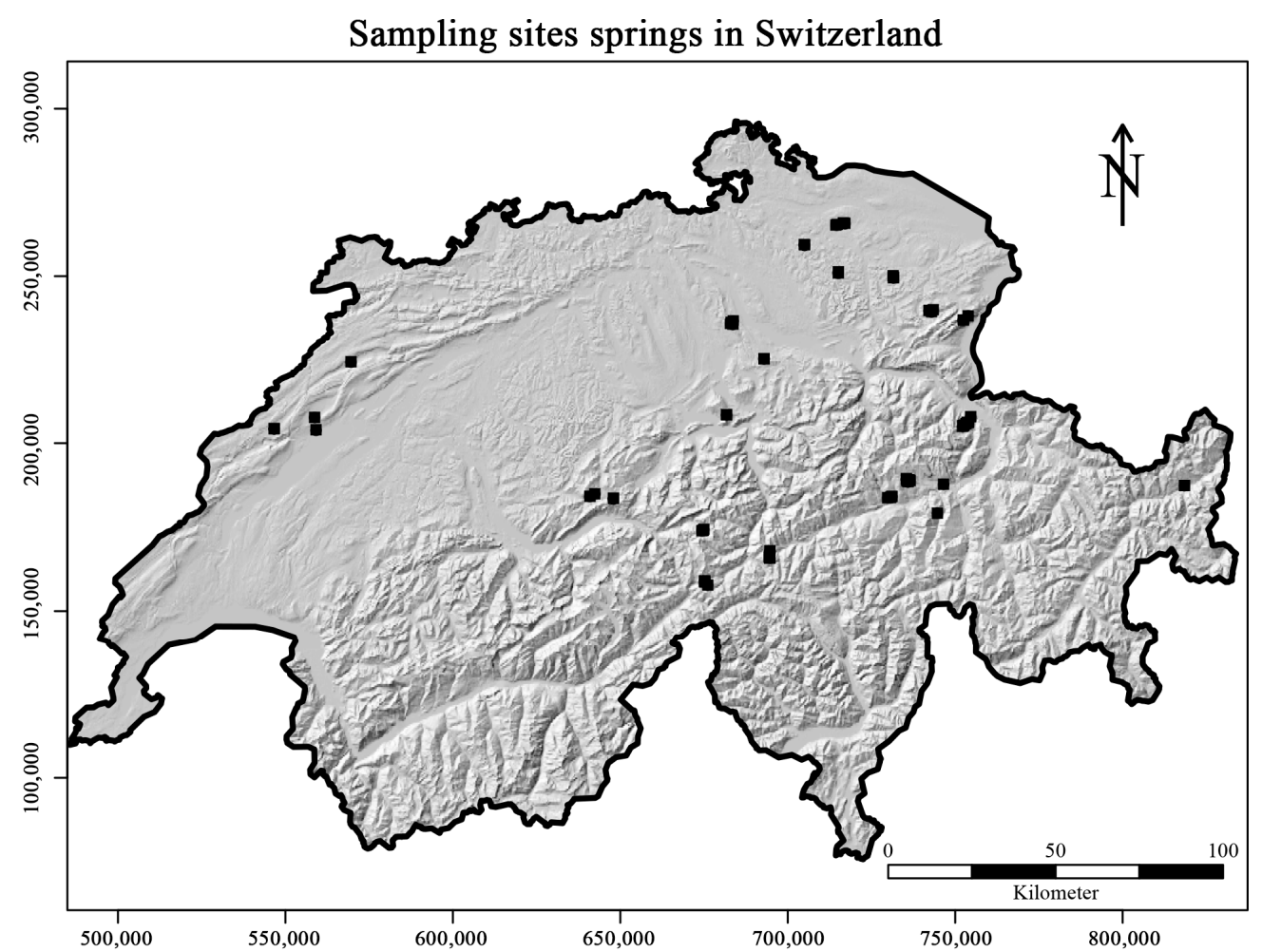

Figure 1. Sampling sites across Switzerland. Overall, 74 springs were sampled on the Swiss Plateau, and in the Alpine foothills and alpine zones. The sites cover an elevation gradient from 491 to $2482 \mathrm{~m}$ above sea level (a.s.l.). Squares overlap when spring sites are located in close proximity. The axes refer to the Swiss coordinate system (Swiss grid).

\subsection{Identification}

Identification was carried out at $1000 \times$ magnification (oil immersion) using an Olympus Vanox AH-2 microscope with differential interference contrast (DIC) (Olympus Schweiz AG, Volketswil, Switzerland). Species identification was based on the most recent literature. The main identification references were: Diatoms of Europe [29-34], Iconographia Diatomologica [7,35,36], and Bibliotheca Diatomologica $[37,38]$. Occasional revisions of species (e.g., [15,39]) were also consulted. The Süsswasserflora von Mitteleuropa 2/1-2/4 [40-43] and Hofmann et al. [44] were used only for taxa for which more recent or more specific literature was not available.

\subsection{Species Lists}

For each counted slide, a species list was produced with relative abundance and Red List status [45] for each species. The Red List covers diatom species in Germany from freshwater and brackish waters. The nomenclature is based on "Süsswasserflora von Mitteleuropa: Bacillariophyceae 
1-4" $[40-42,46]$. The Red List covers eleven categories: $0=$ extinct, $1=$ close to extinct, $2=$ critically endangered, 3 = endangered, $G=$ probably threatened, $R=$ very rare, $V=$ near-threatened, ${ }^{*}=$ not threatened at the moment, ${ }^{* *}=$ definitely unthreatened, $\mathrm{D}=$ data missing, and ${ }^{\circ}=$ to be expected in the area. To avoid bias among counting lists, a minimum of 500 (and not more than 518 valves) was counted. Every species list contained taxa for which the identification to species level was not possible, but in all cases identification to genus level was possible. To determine species richness and all of the respective percentages of frequency classes and Red List categories, we used only taxa identified to the species level.

\subsection{Species Red List Status and Rareness Weighting}

The Swiss Diatom Index (DI-CH) is based on diatom communities collected from stones. Thus, in order to compare species richness, proportions of threatened Red List species, frequency class, and species rareness weighting in our spring dataset with data from the DI-CH, we used only data from stone substrate. Additionally, we present key numbers and figures from the other substrates. To compare regional versus local diversity, we assigned every species a Red List status, a frequency class, and a species rareness weighting $r$. Red List status was based on the German Red List of endangered species [45]. Species were assigned to three different classes: "RL" = species with a threat status (Red List categories 0, 1, 2, 3, G, R, V), "NT" = species considered as not threatened (Red List categories $\left.{ }^{*},{ }^{* *}\right)$, and "NS" $=$ species that were not listed in the Red List (Red List categories D, $\left.{ }^{\circ}\right)$. We took the abundance of each species in the dataset of the Swiss Diatom Index (DI-CH, AquaPlus, unpublished data, $N=6008$ samples), and assigned the species to frequency classes. The DI-CH dataset originates from routine diatom sampling in Swiss freshwater rivers and streams over the past 25 years. The majority of the DI-CH sites are located in the Alpine foothills and the Swiss Plateau, and a minority comes from alpine areas. Forty-two per cent of the DI-CH sites can be considered as oligotrophic habitats (DI-CH < 2.5) [28]. Following the recommendations of Hürlimann et al. (2007), all DI-CH samples were collected in the same way: by brushing the surface of c. 5-10 stones. Species determination followed the taxonomy of "Die Süsswasserflora von Mitteleuropa: Bacillariophyceae $1-4 "$ [40-42,46].

To delimit the frequency classes, we followed the recommendation of Rott et al. [47] but rounded the values as follows: relative abundance $<2 \%=$ very rare $(\mathrm{VR}), 2-5 \%=$ rare $(\mathrm{RA}), 5-20 \%=$ moderately frequent (MF), $20-50 \%$ frequent (FR), and $>50 \%$ = very frequent $(\mathrm{VF})$.

We assigned a species rareness weighting $r$ ranging from 0.01 (not found in the DI-CH database) to 1 (occurs in every sample of the DI-CH database) to each species found in the DI-CH database. For each spring, we calculated a summarised species rareness weighting $r$ depending on species presence (1) and absence (0). We corrected the summarised rareness weighting by the species richness to get $r_{\text {corr }}$ (Formula (1)).

$$
r=\sum_{i=1}^{n} \frac{1}{r_{i}} ; r_{c o r r}=\frac{r}{n}
$$

A summarised species rareness weighting $r$ sums up the inverse value for each species in a spring. $r=$ species rareness weighting of a species, according to its occurrence in the DI-CH dataset (regional species pool). $r$ ranges from 0.01 (not found in the DI-CH) to 1 (found in every sample of the DI-CH). $r_{\text {corr }}=$ species richness corrected. $n=$ number of species found per spring.

\subsection{Spring Alteration Degree (SAD)}

For every spring, we evaluated the degree of alteration according to Lubini et al. [48] and assigned each spring to one of five categories: $1=$ near-natural, 2 = close to near-natural, $3=$ moderately natural, $4=$ moderately altered, and $5=$ massively altered. The method has been created from a faunistic perspective, but many criteria also apply to the needs of autotrophic microflora too. The method gives points between one and five for different structures and disturbances of springs. For example, the more 
a spring is disturbed by artificial structures, waste, discharges (e.g., nutrient inputs, road drainage) or non-resident vegetation, the more alteration points are given. The method considers a great diversity of substrates, different grain sizes, or flow velocities of the water as positive and near-natural.

\subsection{Statistical Analyses}

Variance between the different substrates, species richness, species rareness weighting, and the different Frequency and Red List classes was tested with one-way analysis of variance (ANOVA). Possible correlation between the variables was tested with a Kendall tau $(\tau)$ rank correlation coefficient. We conducted all statistical analyses using the software SPSS Version 22 [49].

\section{Results}

\subsection{Species Richness}

In the 74 springs, 175 samples were collected from the following five substrates: stones $(N=47)$, surface sediment $(N=45)$, bryophytes $(N=57)$, filamentous green-algae $(N=17)$, and leaf litter $(N=9)$. Overall, 504 diatom species were found, and additionally 36 species that could not be identified to species. Per substrate, 346 species on stones could be identified, 361 species on surface sediment, 368 species on bryophytes, 225 species on filamentous green algae, and 132 species on leaf litter (Table 1).

On stones, the minimum number of species per spring was 5 and the maximum 66, with a median of 33. Considering all substrates, the maximum number of species (69) was found on surface sediment in an alpine spring. The median in the DI-CH dataset was 26 species per sample [28] (Hürlimann and Niederhauser 2007).

Table 1. Threat categories and frequency classes of the diatom species found in the different data sets (stones, all substrates per spring, and DI-CH). Coding for Red List status of species follows Lange-Bertalot (1996). Frequency classes refer to the abundancy in the DI-CH dataset. NS = not found in the DI-CH, VR = very rare $(<2 \%), \mathrm{RA}=$ rare $(2-5 \%), \mathrm{MF}=$ moderately frequent $(5-20 \%)$, $\mathrm{FR}=$ frequent $(20-50 \%), \mathrm{VF}=$ very frequent $(>50 \%)$.

\begin{tabular}{ccccc}
\hline & & Stones & Springs & DI-CH \\
\cline { 2 - 5 } & No of datasets $(n)$ & 47 & 175 & 6008 \\
\cline { 2 - 5 } & No of recorded taxa & 346 & 540 & 903 \\
\cline { 2 - 4 } & Average number of species per sample & 33 & 55 & 26 \\
\hline RL (=threatened) & 35.3 & 33.93 & 39.8 \\
& NT (=not threatened) & 33.5 & 32.74 & 41.4 \\
NS (=not specified) & 31.2 & 33.33 & 18.8 \\
& 0 = extinct & 0 & 0 & 0 \\
species (\%) & 1 = close to extinction & 0 & 0 & 0.5 \\
& $2=$ critically endangered & 1.2 & 1.2 & 2.1 \\
& 3 = endangered & 10.4 & 10.1 & 9.2 \\
& $\mathrm{G}=$ probably endangered & 10.1 & 9.9 & 7 \\
& R = very rare & 4.3 & 4 & 9.5 \\
& V = nearly threatened & 9.2 & 8.7 & 11.5 \\
& $*$ not threatened & 18.8 & 17.5 & 21.3 \\
& $* *$ not threatened & 14.7 & 15.3 & 20.2 \\
& not specified & 31.2 & 33.3 & 18.8 \\
\hline DI-CH (\%) & not specified & 31.5 & 36.7 & 0 \\
& very rare & 46.2 & 43.3 & 76.7 \\
& rare & 6.4 & 6.2 & 7.4 \\
& moderately frequent & 7.5 & 6.7 & 9 \\
& frequent & 5.8 & 5.2 & 5.7 \\
& very frequent & 2.6 & 2 & 1.2 \\
\hline
\end{tabular}




\subsection{Red List Status}

Of the species found on stones, $122(=35 \%)$ were Red Listed as threatened, $116(=34 \%)$ as not threatened, and for $108(=31 \%)$ the threat status was not specified (Table 2). The median for threatened Red List species was $29 \%$, for not threatened species $48 \%$, and for species with a not specified threat status $23 \%$. Over all substrates, the maximum of 56\% Red List species was found on a bryophyte sample in an alpine spring. Over all substrates, the median of Red List species was 33\%, that of not threatened species $42 \%$, and that for species with a not specified threat status $24 \%$.

Table 2. Species richness, frequency-class proportions, and Red List status per substrate. $S_{\text {all }}=$ all substrates accumulated, $\mathrm{S}_{\text {sto }}=$ stones, $\mathrm{S}_{\text {sed }}=$ sediment, $\mathrm{S}_{\text {bry }}=$ bryophytes, $\mathrm{S}_{\text {epi }}=$ filamentous green algae, and $\mathrm{S}_{\text {lea }}=$ leaf litter. $\mathrm{SP}=$ number of unidentified species, but identification to genus level was possible. $\mathrm{NS}=$ not found in the $\mathrm{DI}-\mathrm{CH}, \mathrm{VR}=$ very rare $(<2 \%), \mathrm{RA}=$ rare $(2-5 \%), \mathrm{MF}=$ moderately frequent $(5-20 \%), F R=$ frequent $(20-50 \%)$, and $\mathrm{VF}=$ very frequent $(>50 \%)$. Red List status refers to the threat status of the diatom Red List (Lange-Bertalot 1996): RL = species with threat status, NT $=$ species not threatened, NS = threat status not specified. Species and SP are counted species numbers, frequency class DI-CH and Red List status are percentages.

\begin{tabular}{|c|c|c|c|c|c|c|c|c|c|c|c|}
\hline & \multirow[b]{2}{*}{ Species } & \multirow[b]{2}{*}{ SP } & \multicolumn{6}{|c|}{ Frequency Class DI-CH (\%) } & \multicolumn{3}{|c|}{ Red List Status (\%) } \\
\hline & & & NS & VR & RA & MF & FR & VF & RL & NT & NS \\
\hline$S_{\text {all }}$ & 540 & 36 & 36.7 & 43.3 & 6.2 & 6.7 & 5.2 & 2 & 33.9 & 32.7 & 33.3 \\
\hline $\mathrm{S}_{\text {Stone }}$ & 369 & 23 & 31.5 & 46.2 & 6.4 & 7.5 & 5.8 & 2.6 & 35.3 & 33.5 & 31.2 \\
\hline $\mathrm{S}_{\text {sediment }}$ & 382 & 21 & 31.9 & 47.1 & 6.1 & 6.6 & 5.5 & 2.8 & 36 & 34.9 & 29.1 \\
\hline $\mathrm{S}_{\text {bryophytes }}$ & 389 & 21 & 32.9 & 46.5 & 6 & 6.5 & 6 & 2.2 & 34.8 & 33.7 & 31.5 \\
\hline $\mathrm{S}_{\text {filamentous green-algae }}$ & 237 & 12 & 29.3 & 44.9 & 5.3 & 8 & 8.9 & 3.6 & 33.8 & 37.8 & 28.4 \\
\hline$S_{\text {leaf litter }}$ & 134 & 12 & 23 & 47.5 & 7.4 & 9 & 7.4 & 5.7 & 32.8 & 35.2 & 32 \\
\hline
\end{tabular}

\subsection{Species Frequency}

Overall on all substrates, 185 species were absent from the DI-CH dataset $(N=6008$ samples with overall 903 species), 218 species occurred very rarely, 31 rarely, 34 moderately frequently, 26 frequently, and 10 very frequently. On substrate stone, 109 species were absent from the DI-CH dataset, 160 species listed very rarely, 22 rarely, 26 moderately frequently, 20 frequently, and 9 very frequently. Per spring, on average on stones, $17 \%$ of the species could not be assigned to a frequency class (NS), $38 \%$ were very rare species (VR), $8 \%$ rare species (RA), $12 \%$ moderately-frequent species (MF), $14 \%$ frequent species (FR), and 11\% very-frequent species (VF) (Figure 2).

\subsection{Spring Alteration Degree (SAD)}

The majority of the springs were in a near-natural $(N=22)$ or a close-to-natural state $(N=19)$. Five springs were moderately natural, and one spring was moderately altered. No spring was heavily altered. The main disturbance on close-to-natural springs came from cattle (dung, trampling damage). Moderately natural or moderately altered springs were usually damaged by partial water diversion (drains, pipes), or concrete out-flows. There is a highly significant negative correlation between increasing elevation ( $m$ above sea level (a.s.l.)) and the Spring Alteration Degree (SAD): $F(3,43)=6.8$, $p=0.001 ; \tau(47)=-0.44, p<0.001)($ Figure 3 C). 
A

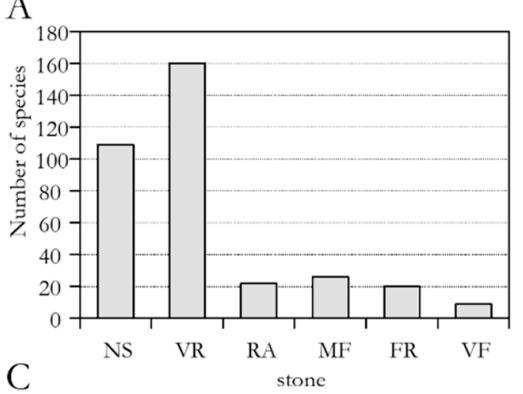

C

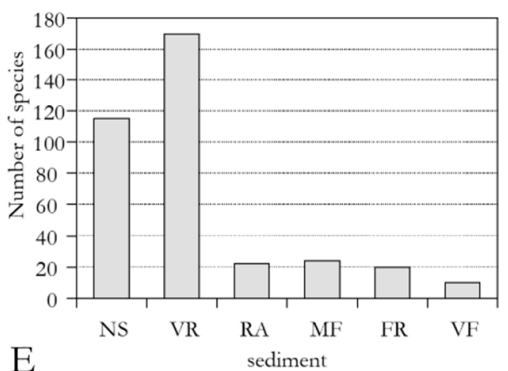

E

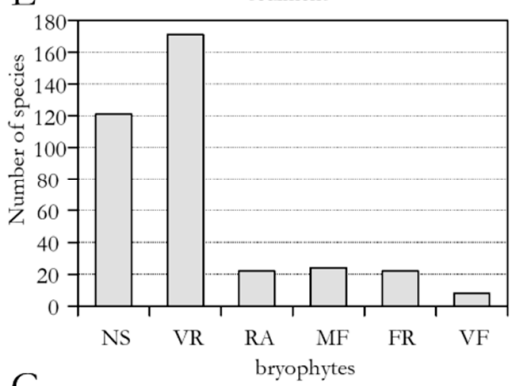

G

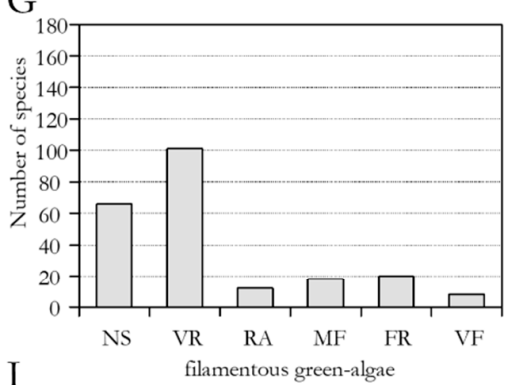

I

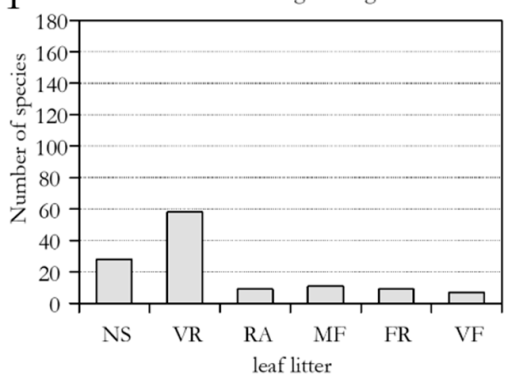

B

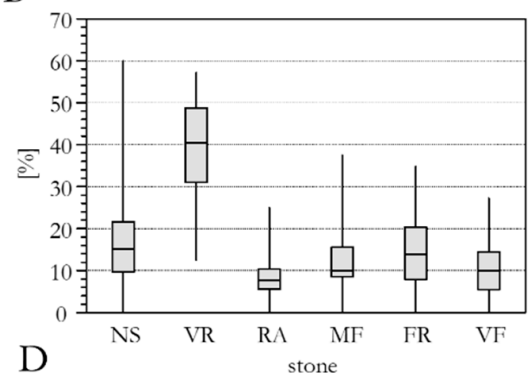

D

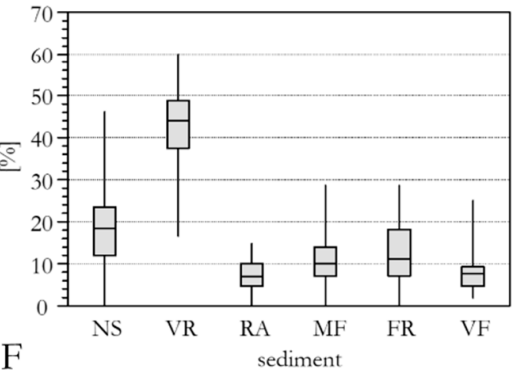

F

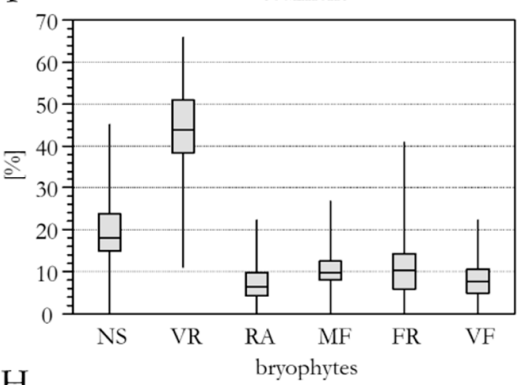

$\mathrm{H}$
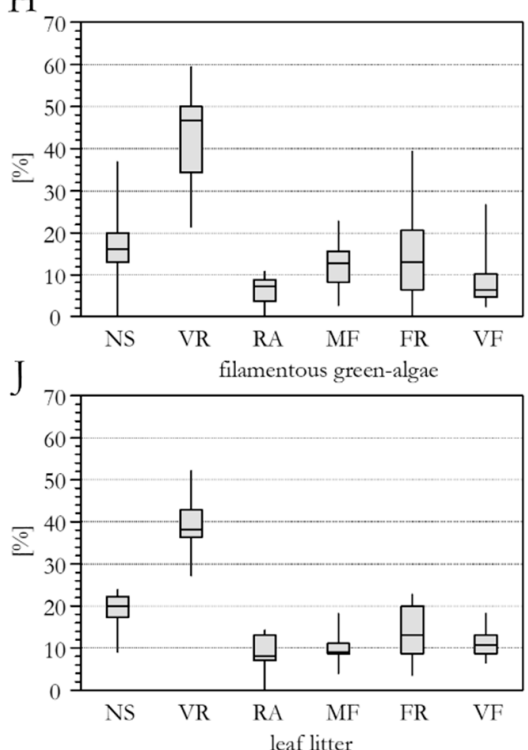

Figure 2. Bar charts showing the total number of species in the respective frequency classes on the different substrates: (A) stones; (C) surface sediment; (E) bryophytes; (G) filamentous green-algae; and (I) leaf litter. Box plots show the distribution of percentages per sampling site for each frequency class on the different habitats: (B) stones; (D) surface sediment; (F) bryophytes; (H) filamentous green-algae; and (J) leaf litter. The boundary of the box shows the 25th and 75th percentile, the line within the box shows the median, and the whiskers the maxima and minima. Frequency classes refer to the abundance in the DI-CH dataset. NS = not found in the DI-CH, VR = very rare $(<2 \%), \mathrm{RA}=$ rare $(2-5 \%), \mathrm{MF}=$ moderately frequent $(5-20 \%), \mathrm{FR}=$ frequent $(20-50 \%), \mathrm{VF}=$ very frequent $(>50 \%)$. 
A

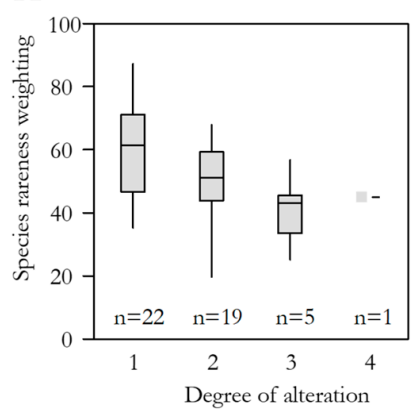

$\mathrm{D}$

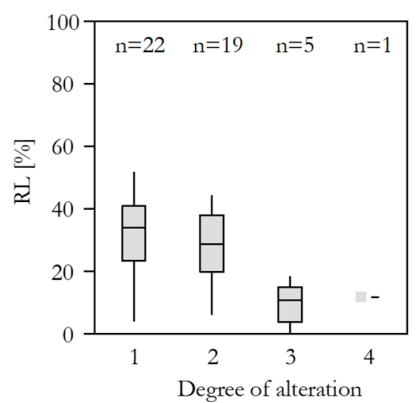

$\mathrm{B}$

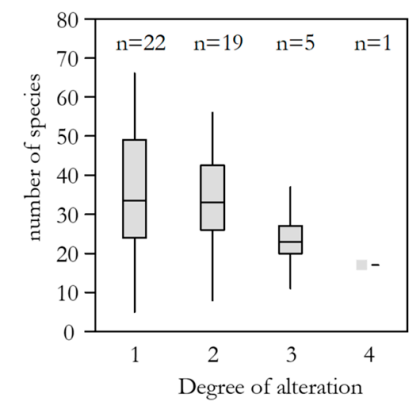

E

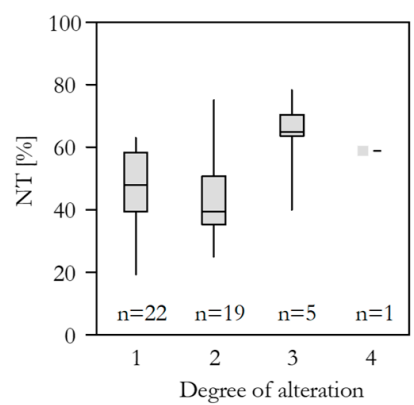

C

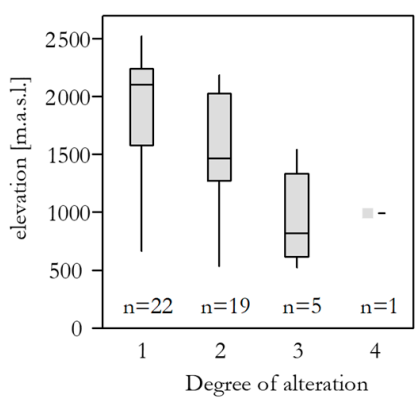

$\mathrm{F}$

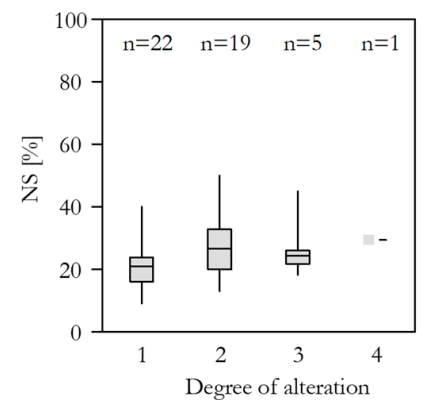

Figure 3. Biodiversity variables and elevation in relation to the Spring Alteration Degree (SAD) for samples taken from stones. (A) Species rareness weighting; (B) species richness; and (C) elevation of the springs. There is a significant negative association between species rareness weighting and SAD $(F(3,43)=8.4, p=0.006 ; \tau(47)=-0.34, p=0.004)$. No difference was found between number of species per spring and $\operatorname{SAD}(\mathrm{F}(3,43)=1.48, p=0.231 ; \tau(47)=-0.19, p=0.101)$. The SAD decreased significantly with elevation (m a.s.l.) $(\mathrm{F}(3,43)=6.8, p=0.001 ; \tau(47)=-0.44, p<0.001)$. Red List status proportions in relation to the SAD on the substrate stone ( $N=47)$; (D) Abundance of species with a threat status (RL) on the Red List; (E) Per cent abundance of species that are considered as not threatened (NT) on the Red List; (F) Per cent abundance of species with a not specified threat status (NS). The boundary of the box shows the 25th and 75th percentile, the line within the box shows the median, and the whiskers the maxima and minima.

\subsection{Species Richness, Red List Threat Status, Frequency in the DI-CH, and Spring Alteration Degree (SAD)}

On stones, undisturbed springs had the highest percentages of diatom species that were not abundant in the DI-CH dataset. There was a significant difference among the mean values of the species rareness weighting for springs assigned to the different SAD levels. Furthermore, there was a negative correlation between summarized species rareness weighting and the SAD (Figure 3A). However, there was no significant difference between the mean values for the species richness of the springs in each SAD category (Figure 3B). The mean values for very rare (VR) and frequent (FR) species did not differ significantly between different SAD levels. However, the mean values for very rare (VR) species showed a negative, and the mean values for frequent (FR) species a positive correlation with SAD. The mean values of very frequently $(\mathrm{VF})$ found species differed significantly and correlated positively with the different SAD levels (Table 3, Figure 4). The mean values of the Red List species percentages (RL) were significantly different and correlated negatively with the SAD levels. On the contrary, there was a significant difference among the mean values of the unthreatened species (NT) but no correlation between the different SAD levels. The mean values of species with no threat status (NS) had no significant difference, but showed weak correlation with increasing SAD (Table 3, Figure 3). 
Table 3. Results of the ANOVA and correlation test between the single variables for each substrate. One-way analysis of variance (ANOVA) shows F- and $p$-values (level of significance $=5 \%$ ). Kendall's rank correlation coefficient shows the coefficent $\tau$ and the significance $(p)$ depending on the SAD. Highlighted in bold are significant results $(p<0.05)$, and a grey background indicates a significant difference of the means by ANOVA and significant correlation by Tau-test. Frequency classes refer to the occurrence of species in the DI-CH (regional species pool): VR = very rare, $\mathrm{RA}=$ rare, $\mathrm{MF}=$ moderately frequent, $\mathrm{FR}=$ frequent, $\mathrm{VF}=\mathrm{very}$ frequent, NS = not found in the DI-CH. Red List status refers to the German diatom Red List (Lange-Bertalot 1996): RL = species are considered as threatened, NT = species are considered as not threatened, NS = threat status not specified.

\begin{tabular}{|c|c|c|c|c|c|c|c|c|c|c|c|c|c|}
\hline \multirow{2}{*}{ Substrate } & \multirow{2}{*}{ Analysis } & & \multirow{2}{*}{ Species Rareness Weighting } & \multirow{2}{*}{ Species Richness } & \multicolumn{6}{|c|}{ Frequency Classes } & \multicolumn{3}{|c|}{ Red List Status } \\
\hline & & & & & VR & RA & MF & FR & VF & NS & RL & NT & NS \\
\hline \multirow{3}{*}{ Stone } & \multirow{2}{*}{ ANOVA } & $\mathrm{F}(3,43)$ & 2.96 & 1.48 & 2.35 & 1.51 & 0.39 & 2.49 & 3.05 & 1.48 & 5.60 & 3.09 & 2.17 \\
\hline & & $\mathrm{p}$ & 0.042 & 0.231 & 0.085 & 0.225 & 0.758 & 0.073 & 0.039 & 0.232 & 0.002 & 0.037 & 0.105 \\
\hline & Kendall $\tau$ & $\mathrm{p}$ & 0.004 & 0.101 & 0.022 & 0.160 & 0.467 & 0.015 & 0.010 & 0.104 & 0.003 & 0.327 & 0.015 \\
\hline \multirow{4}{*}{ Sediment } & \multirow{2}{*}{ ANOVA } & $\mathrm{F}(3,41)$ & 3.37 & 2.39 & 2.78 & 1.12 & 2.28 & 1.75 & 3.62 & 1.59 & 4.57 & 1.04 & 5.06 \\
\hline & & $\mathrm{p}$ & 0.027 & 0.083 & 0.053 & 0.350 & 0.093 & 0.171 & 0.021 & 0.206 & 0.007 & 0.386 & 0.004 \\
\hline & \multirow{2}{*}{ Kendall $\tau$} & $\tau(45)$ & -0.30 & -0.24 & -0.29 & 0.15 & 0.15 & 0.24 & 0.35 & -0.14 & -0.39 & 0.17 & 0.27 \\
\hline & & $\mathrm{p}$ & 0.012 & 0.043 & 0.013 & 0.214 & 0.214 & 0.042 & 0.003 & 0.223 & 0.001 & 0.152 & 0.022 \\
\hline \multirow{4}{*}{ Bryophytes } & \multirow{2}{*}{ ANOVA } & $\mathrm{F}(2,54)$ & 3.26 & 0.51 & 5.10 & 1.46 & 0.78 & 2.77 & 6.35 & 0.05 & 3.52 & 0.83 & 3.16 \\
\hline & & $\mathrm{p}$ & 0.046 & 0.605 & 0.009 & 0.241 & 0.465 & 0.071 & 0.003 & 0.948 & 0.037 & 0.444 & 0.050 \\
\hline & \multirow{2}{*}{ Kendall $\tau$} & $\tau(57)$ & -0.19 & -0.09 & -0.30 & 0.03 & -0.03 & 0.21 & 0.38 & 0.00 & -0.19 & 0.11 & 0.19 \\
\hline & & $\mathrm{p}$ & 0.080 & 0.379 & 0.005 & 0.797 & 0.750 & 0.054 & 0.000 & 0.975 & 0.075 & 0.319 & 0.077 \\
\hline \multirow{4}{*}{$\begin{array}{l}\text { Filamentous } \\
\text { green-algae }\end{array}$} & \multirow{2}{*}{ ANOVA } & $\mathrm{F}(3,13)$ & 1.03 & 0.65 & 4.59 & 0.52 & 0.80 & 2.81 & 1.46 & 0.52 & 4.43 & 2.35 & 0.46 \\
\hline & & $\mathrm{p}$ & 0.412 & 0.595 & 0.021 & 0.667 & 0.516 & 0.081 & 0.271 & 0.674 & 0.024 & 0.120 & 0.716 \\
\hline & \multirow{2}{*}{ Kendall $\tau$} & $\tau(17)$ & -0.35 & -0.06 & -0.34 & 0.00 & 0.06 & 0.43 & 0.30 & -0.38 & -0.50 & 0.45 & 0.16 \\
\hline & & $\mathrm{p}$ & 0.081 & 0.754 & 0.088 & 1.000 & 0.754 & 0.032 & 0.128 & 0.060 & 0.012 & 0.023 & 0.420 \\
\hline \multirow{3}{*}{ Leaf litter } & ANOVA & $\mathrm{p}$ & 0.805 & 0.251 & 0.458 & 0.999 & 0.734 & 0.481 & 0.732 & 0.947 & 0.781 & 0.836 & 0.287 \\
\hline & \multirow{2}{*}{ Kendall $\tau$} & $\tau(9)$ & 0.03 & 0.36 & -0.24 & 0.03 & -0.21 & 0.17 & 0.24 & -0.03 & 0.17 & 0.07 & -0.49 \\
\hline & & $\mathrm{p}$ & 0.906 & 0.233 & 0.408 & 0.906 & 0.477 & 0.555 & 0.408 & 0.906 & 0.555 & 0.812 & 0.097 \\
\hline
\end{tabular}

Note: Numbers in shaded and bold cells show significant results. 
For comparison, we did the same analysis with the other substrates, and found similar correlation trends with sediment and bryophytes for species rareness weighting, very rare and very frequent species, and Red List species percentages in relation to SAD (Table 3). On sediment, only the mean values of summarized species rareness weighting differed significantly, but summarised species rareness weighting and species richness were both negatively correlated with SAD. The number of very rare (VR) species had significantly different mean values and decreased with SAD. The means of frequent species (FR) did not differ, and the means of very frequent species (VR) did differ significantly, but both correlated positively with SAD. The means of Red List species were significantly different and decreased with SAD, and the mean percentages of species with a not specified threat status were also significantly different but increased with SAD.

On bryophytes, summarised species rareness weighting showed significantly different means but not significant correlation. Very rarely found species (VR) had different means and correlated negatively with SAD, and the amount of very frequent species (VF) had significantly different means and correlated positively with SAD. Red List species and species with no specified threat status had significantly different mean values, but the correlation with SAD was not significant.

For the other substrates, no trends or correlations could be found, except for threatened Red List species (RL) on filamentous green algae, where there was a significant difference in the means and a negative correlation with the SAD could be found (Table 3).

A

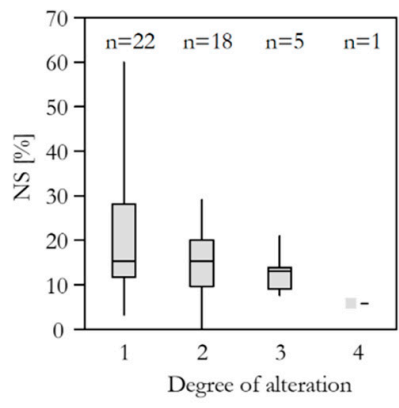

$\mathrm{D}$

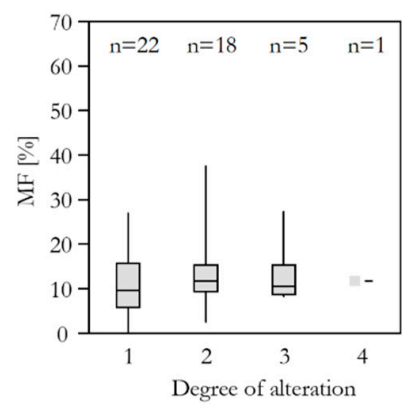

B

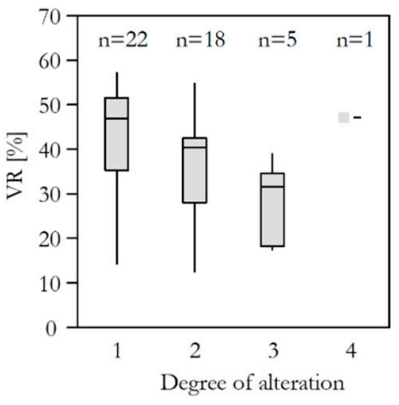

$\mathrm{E}$

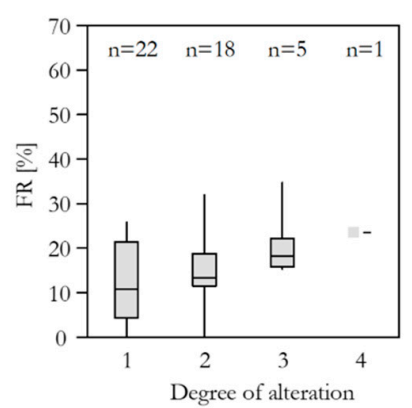

C

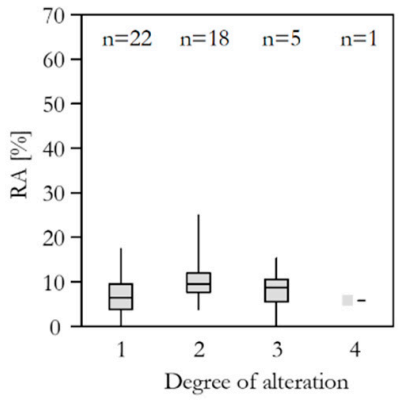

F

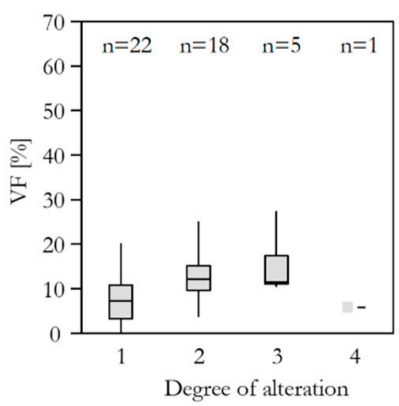

Figure 4. Percentages of species belonging to the respective DI-CH frequency classes in relation to the $\mathrm{SAD}$ on the substrate stone. $\mathrm{NS}=$ not found in the $\mathrm{DI}-\mathrm{CH}, \mathrm{VR}=$ very rare $(<2 \%), \mathrm{RA}=$ rare $(2-5 \%), \mathrm{MF}$ $=$ moderately frequent $(5-20 \%), \mathrm{FR}=$ frequent $(20-50 \%), \mathrm{VF}=$ very frequent $(>50 \%)$. The boundary of the box shows the 25th and 75th percentile, the line within the box shows the median, and the whiskers the maxima and minima.

\section{Discussion}

Swiss epilithic diatom communities are more species-rich in springs (average $=33$ species per sample) than in streams (average $=26$ species per sample [28]). However, because the raw data from the stream floras were not available, we could not test the significance. With increasing $\mathrm{SAD}$, the proportions of Red List species decrease. These trends are similarly high on all substrates 
(i.e., microhabitats) in springs. The SAD decreases with increasing elevation and decreasing land use intensity. Consequently, we consider near-natural springs to be refugial habitats for sensitive and endangered diatom species, because springs are rich in species that do not or only rarely occur in running waters, and because the fraction of rare species decreases with an increasing degree of alteration.

The highest species richness was found on the substrate bryophytes. This is in agreement with several papers that have shown that bryophytes are the most diatom species-rich substrate in springs. Consequently, bryophytes were proposed as standard substratum for the sampling of diatom assemblages in springs by, e.g., Cantonati et al. ([17] and references therein). However, in this study, the proportions of species with Red List status and the percentages of rare species were similar among substrates. The substrate sediment should be considered with caution because diatom frustules and valves are very resistant to degradation, and the diatom richness found on this substrate with traditional methods can integrate assemblages that have developed over a longer time span [50].

Our study revealed that near-natural springs have higher percentages of both endangered Red List species and of species undetected or very rarely found in the regional species pool. These proportions are significantly smaller in impaired springs. Hence, our findings support the suitability of near-natural springs as habitats for Least-Impaired Habitat Relicts (LIHRe). However, this is still an inference. For confirmation, it would be necessary to show that at least some diatom species, which may previously have been more widespread in other freshwater habitats, are now confined to near-natural springs.

Zollhöfer [51] estimated that $41 \%$ of the springs on the Swiss Plateau and $67 \%$ of the springs in the Jura Mountain disappeared as near-natural habitats as a result of human exploitation between 1884 and 1990. By 1990, 94\% of the remaining Swiss Plateau springs, and 40\% of the remaining Jura Mountains springs, had been walled or otherwise altered. These results are congruent with our finding that near-natural springs are found more frequently at higher elevations. The Swiss Plateau is densely populated and agriculturally intensely used, whereas the Jura Mountains are less densely populated and possess more springs that are still in a near-natural state.

Raw species richness is an inadequate indicator of LIHRe. However, the number of regionally rare species was higher in near-natural springs. Altering these habitats may result in the loss of species that are rare in the regional species pool. The comparison of the stream diatom dataset (DI-CH) with the spring dataset (this study) showed that threatened Red List and rare species are less frequent in streams. Streams are on average more impacted and altered than springs. This was confirmed by qualitative observations by Cantonati and Spitale [52], who compared 16 springs and 5 streams in the Dolomiti Bellunesi National Park. Even if the low number of streams did not allow for statistical testing, some qualitative results, such as the occurrence of typical pollution-tolerant diatoms in streams only and of rare and new-to-science species in springs only, support this interpretation.

Although flowing springs (as the majority of those that we considered) are generally connected with the running water system downstream and with its species pool, a considerable proportion of the species pool is not shared between these two habitats (e.g., Cantonati and Lange-Bertalot [13]). Our findings add further support to general qualitative observations by Falasco et al. [19], who highlighted the importance of mountain springs as a source of diatom biodiversity, including rare species. It is still unclear how diatoms reach springs. Vyverman et al. [27] showed for diatoms in lake habitats not only a significant correlation between the regional species pool and the diversity of local communities, but also the influence of habitat availability on regional and local species richness. Experimental evidence confirmed that intact connectivity between running water habitats is of crucial importance for regional biodiversity [53]. If dispersal is limited, river networks can become a trap for species [54]. In our case, springs can be traps for diatom species that cannot find suitable habitats downriver because of dispersal constraints. Kociolek and Stoermer [55] stressed the importance of oligotrophic habitats. In only a few small samples from three oligotrophic lakes, Lange-Bertalot and Metzeltin [35] found over 800 species, many of them new to science. Most springs are oligotrophic 
habitats as well, and offer rare diatom species a habitat to survive. Given the value of freshwater biodiversity [3], springs can play a crucial role in conserving biodiversity, and act as refugia for sensitive and endangered diatom species.

Acknowledgments: We are very grateful to Joachim Hürlimann (AquaPlus AG, Zug) for making the DI-CH dataset available. LT was funded by Hermann Klaus Stiftung, Claraz-Schenkung, and the University of Zurich. MC was partially funded by the Autonomous Province of Trento while contributing to this study. We also thank two anonymous reviewers for their helpful comments that improved the manuscript.

Author Contributions: L.T., H.P.L., and M.C. conceived and designed the experiments and analysed the data; L.T. performed the laboratory work, data analysis, and wrote the paper with input from M.C. and H.P.L.

Conflicts of Interest: The authors declare no conflict of interest.

\section{References}

1. Strayer, D.L.; Dudgeon, D. Freshwater biodiversity conservation: Recent progress and future challenges. J. N. Am. Benthol. Soc. 2010, 29, 344-358.

2. Baur, B.; Duelli, P.; Edwards, P.J.; Jenny, M.; Klaus, G.; Künzle, I.; Martinez, S.; Pauli, D.; Peter, K.; Schmid, B.; et al. Biodiversität der Schweiz: Zustand, Erhaltung, Perspektive. Wissenschaftliche Grundlagen für eine Nationale Strategie; Haupt Verlag: Bern, Germany, 2004; p. 236.

3. Dudgeon, D.; Arthington, A.H.; Gessner, M.O.; Kawabata, Z.I.; Knowler, D.J.; Leveque, C.; Naiman, R.J.; Prieur-Richard, A.H.; Soto, D.; Stiassny, M.L.J; et al. Freshwater biodiversity: Importance, threats, status and conservation challenges. Biol. Rev. 2006, 81, 163-182. [PubMed]

4. Cantonati, M.; Füreder, L.; Gerecke, R.; Jüttner, I.; Cox, E.J. Crenic habitats, hotspots for freshwater biodiversity conservation: Toward an understanding of their ecology. Freshw. Sci. 2012, 31, 463-480. [CrossRef]

5. Gerecke, R.; Franz, H.; Cantonati, M. Invertebrate diversity in springs of the National Park Berchtesgaden (Germany): Relevance for long-term monitoring. Verh. Internat. Verein. Limnol. 2009, 30, 1229-1233.

6. Zechmeister, H.; Mucina, L. Vegetation of European springs-High-rank syntaxa of the Montio-Mardaminetea. J. Veg. Sci. 1994, 5, 385-402. [CrossRef]

7. Werum, M.; Lange-Bertalot, H. Diatoms in Springs from Central Europe and Elsewhere under the Influence of Hydrogeology and Anthropogenic Impacts; A.R.G. Gantner Verlag K.G.: Ruggell, Liechtenstein, 2004; p. 480.

8. Van der Kamp, G. The hydrogeology of springs in relation to the biodiversity of spring fauna-A review. J. Kans. Entomol. Soc. 1995, 68, 4-17.

9. Cantonati, M.; Gerecke, R.; Bertuzzi, E. Springs of the Alps-Sensitive ecosystems to environmental change: From biodiversity assessments to long-term studies. Hydrobiologia 2006, 562, 59-96.

10. Fránkóva, M.; Bojkova, J.; Poulickova, A.; Hajek, M. The structure and species richness of the diatom assemblages of the western Carpathian spring fens along the gradient of mineral richness. Fottea 2009, 9 , 355-368. [CrossRef]

11. Gesierich, D.; Kofler, W. Epilithic diatoms form rheocrene springs in the eastern Alps (Vorarlberg, Austria). Diatom Res. 2010, 25, 43-66. [CrossRef]

12. Żelazna-Wieczorek, J. Diatom Flora in Springs of Lódz Hills (Central Poland). Biodiversity, Taxonomy, and Temporal Changes of Epipsammic Diatom Assemblages in Springs Affected by Human Impact; A.R.G. Gantner Verlag K.G.: Ruggell, Liechtenstein, 2011; p. 419.

13. Cantonati, M.; Lange-Bertalot, H. Diatom biodiversity of springs in the Berchtesgaden National Park (north-eastern Alps, Germany), with the ecological and morphological characterization of two species new to science. Diatom Res. 2010, 25, 251-280.

14. Cantonati, M.; Lange-Bertalot, H.; Scalfi, A.; Angeli, N. Cymbella tridentina sp. nov. (Bacillariophyta), a crenophilous diatom from carbonate springs of the Alps. J. N. Am. Benthol. Soc. 2010, 29, 775-788. [CrossRef]

15. Levkov, Z.; Ector, L. A comparative study of Reimeria species (Bacillariophyceae). Nova Hedwig. 2010, 90, 469-489. [CrossRef]

16. Gerecke, R. A new species and subgenus of Lebertia (Acari: Hydrachnidia: Lebertiidae) from the Brenta-Adamello natural park (Italian Alps). Fundam. Appl. Limnol. 2008, 170, 325-332. [CrossRef]

17. Cantonati, M.; Angeli, N.; Bertuzzi, E.; Spitale, D.; Lange-Bertalot, H. Diatoms in springs of the Alps: Spring types, environmental determinants, and substratum. Freshw. Sci. 2012, 31, 499-524. [CrossRef] 
18. Grasby, S.E.; Londry, K.L. Biogeochemistry of hypersaline springs supporting a mid-continent marine ecosystem: An analogue for martian springs? Astrobiology 2007, 7, 662-683. [CrossRef] [PubMed]

19. Falasco, E.; Ector, L.; Ciaccio, E.; Hoffmann, L.; Bona, F. Alpine freshwater ecosystems in a protected area: A source of diatom diversity. Hydrobiologia 2012, 695, 233-251. [CrossRef]

20. Botosaneanu, L. Springs as refugia for geographic relicts. Crunoecia 1995, 4, 5-9.

21. Baas Becking, L.G.M. Geobiologie of Inleiding tot de Milieukunde; W. P. Van Stockum \& Zoon: The Hague, The Netherlands, 1934.

22. Fenchel, T.; Finlay, B.J. The ubiquity of small species: Patterns of local and global diversity. Bioscience 2004, 54, 777-784. [CrossRef]

23. Finlay, B.J.; Monaghan, E.B.; Maberly, S.C. Hypothesis: The rate and scale of dispersal of freshwater diatom species is a function of their global abundance. Protist 2002, 153, 261-273. [CrossRef] [PubMed]

24. Hillebrand, H.; Watermann, F.; Karez, R.; Berninger, U.-G. Differences in species richness patterns between unicellular and multicellular organisms. Oecologia 2001, 126, 114-124. [CrossRef] [PubMed]

25. Foissner, W. Protist diversity and distribution: Some basic considerations. Biodivers. Conserv. 2008, 17, 235-242. [CrossRef]

26. Telford, R.J.; Vandvik, V.; Birks, H.J.B. Dispersal limitations matter for microbial morphospecies. Science 2006, 312, 1015. [CrossRef] [PubMed]

27. Vyverman, W.; Verleyen, E.; Sabbe, K.; Vanhoutte, K.; Sterken, M.; Hodgson, D.A.; Mann, D.G.; Juggins, S.; Van de Vijver, B.; Jones, V.; et al. Historical processes constrain patterns in global diatom diversity. Ecology 2007, 88, 1924-1931. [CrossRef] [PubMed]

28. Hürlimann, J.; Niederhauser, P. Methoden zur Untersuchung und Beurteilung der Fliessgewässer. Kieselalgen Stufe F (Flächendeckend). Umwelt-Vollzug Nr. 0740; Bundesamt für Umwelt: Bern, Germany, 2007; p. 130.

29. Krammer, K. Cymbopleura, Delicata, Navicymbula, Gomphocymbellopsis, Afrocymbella; A.R.G. Gantner Verlag K.G.: Ruggell, Liechtenstein, 2000; Volume 4, p. 530.

30. Krammer, K. Cymbella; A.R.G. Gantner Verlag K.G.: Ruggell, Liechtenstein, 2002; Volume 3, p. 584.

31. Krammer, K. Pinnularia; A.R.G. Gantner Verlag K.G.: Ruggell, Liechtenstein, 2002; Volume 1, p. 703.

32. Lange-Bertalot, H. Navicula Sensu Stricto, 10 Genera Separated from Navicula Sensu lato, Frustulia; A.R.G. Gantner Verlag K.G.: Ruggell, Liechtenstein, 2001; Volume 2, p. 526.

33. Lange-Bertalot, H.; Bak, M.; Witkowski, A. Eunotia and Some Related Genera; A.R.G. Gantner Verlag K.G.: Ruggell, Liechtenstein, 2011; Volume 6, p. 747.

34. Levkov, Z. Amphora Sensu Lato; A.R.G. Gantner Verlag K.G.: Ruggell, Liechtenstein, 2009; Volume 5, p. 916.

35. Lange-Bertalot, H.; Metzeltin, D. Indicators of Oligotropy. 800 Taxa Representative of Three Ecologically Distinct Lake Types Carbonate Buffered, Oligodystrophic, Weakly Buffered Soft Water; Koeltz: Königstein, Germany, 1996; p. 390.

36. Reichardt, E. Zur Revision der Gattung Gomphonema. Die Arten um G. affine/insigne, G. angustatum/micropus, G. acuminatum Sowie Gomphonemoide Diatomeen aus dem Oberoligozän in Böhmen; A.R.G. Gantner Verlag K.G.: Ruggell, Liechtenstein, 1999; p. 203.

37. Krammer, K. Die cymbelloiden Diatomeen. Teil 2. Encyonema Part., Encyonopsis und Cymbellopsis. Eine Monographie der Weltweit Bekannten Taxa; J. Cramer: Berlin/Stuttgart, Germany, 1997; Volume 37, p. 469.

38. Krammer, K. Die cymbelloiden Diatomeen. Teil 1. Allgemeines und Encyonema Part. Eine Monographie der Weltweit Bekannten Taxa; J. Cramer: Berlin/Stuttgart, Germany, 1997; Volume 36, p. 382.

39. Reichardt, E. Taxonomic revision of the species complex involving Gomphonema pumilum (Bacillariophyceae). Nova Hedwig. 1997, 65, 99-129.

40. Krammer, K.; Lange-Bertalot, H. Bacillariophyceae. 3. Teil: Centrales, Fragilariaceae, Eunotiaceae; Gustav Fischer Verlag: Stuttgart, Germany; New York, NY, USA, 1991; Volume 2, p. 576.

41. Krammer, K.; Lange-Bertalot, H. Bacillariophyceae. 4. Teil: Achnanthaceae, Kritische Ergänzungen zu Navicula (Lineolatae) und Gomphonema. Gesamtliteraturverzeichnis Teil 1-4; Gustav Fischer Verlag: Stuttgart, Germany; New York, NY, USA, 1991; Volume 2/4, p. 437.

42. Krammer, K.; Lange-Bertalot, H. Bacillariophyceae. 2. Teil: Bacillariaceae, Epithemiaceae, Surirellaceae. Unveränderter Nachdruck; Gustav Fischer Verlag: Stuttgart, Germany; New York, NY, USA, 2007; Volume 2/2, p. 611.

43. Krammer, K.; Lange-Bertalot, H. Bacillariophyceae 1. Teil: Naviculaceae; Spektrum Verlag: Heidelberg, Germany, 2010. 
44. Hofmann, G.; Werum, M.; Lange-Bertalot, H. Diatomeen im Süsswasser-Benthos von Mitteleuropa. Bestimmungsflora Kieselalgen für die Ökologische Praxis. Über 700 der Häufigsten Arten und Ihre Ökologie; A.R.G. Gantner Verlag K.G.: Ruggell, Liechtenstein, 2011; p. 908.

45. Lange-Bertalot, H. Rote Liste der limnischen Kieselalgen (Bacillariophyceae) Deutschlands. In Rote Liste gefährdeter Pflanzen Deutschlands; Bundesamt für Naturschutz: Bonn-Bad Godesberg, Germany, 1996; Volume 28, pp. 633-678.

46. Krammer, K.; Lange-Bertalot, H. Bacillariophyceae. 1. Teil: Naviculaceae; Gustav Fischer Verlag: Stuttgart, Germany; New York, NY, USA, 1986; Volume 2/1, p. 876.

47. Rott, E.; Pfister, P.; Van Dam, H.; Pipp, E.; Pall, K.; Binder, N.; Ortler, K. Indikationslisten für Aufwuchsalgen in Österreichischen Fliessgewässern. Teil 2: Trophieindikation Sowie Geochemische Präferenz; Taxonomische und Toxikologische Anmerkungen; Bundesministerium für Land- und Forstwirtschaft, Wasserwirtschaftskataster: Wien, Austria, 1999; p. 248.

48. Lubini, V.; Stucki, P.; Vincentini, H.; Küry, D. Ökologische Bewertung von Quell-Lebensräumen in der Schweiz. Entwurf für ein Strukturelles und Faunistisches Verfahren; Bundesamtes für Umwelt: Bern, Swizterland, 2014; p. 47.

49. International Business Machines Corporation (IBM). IBM SPSS Statistics; Version 22; IBM Corp.: Armonk, NY, USA, 2014.

50. Taxböck, L.; Karger, D.N.; Cantonati, M.; Kessler, M. Diatom species richness and compositional turnover in swiss near-natural springs. Plant Ecol. Divers. 2017, in preparation.

51. Zollhöfer, J.M. Spring Biotopes in Northern Switzerland: Habitat Heterogeneity, Zoobenthic Communities and Colonization Dynamics. Ph.D. Dissertation, ETH Zürich, Zürich, Switzerland, 1999.

52. Cantonati, M.; Spitale, D. The role of environmental variables in structuring epiphytic and epilithic diatom assemblages in springs and streams of the Dolomiti Bellunesi national park (south-eastern Alps). Fundam. Appl. Limnol. 2009, 174, 117-133. [CrossRef]

53. Carrara, F.; Altermatt, F.; Rodriguez-Iturbe, I.; Rinaldo, A. Dendritic connectivity controls biodiversity patterns in experimental metacommunities. Proc. Natl. Acad. Sci. USA 2012, 109, 5761-5766. [CrossRef] [PubMed]

54. Carrara, F.; Rinaldo, A.; Giometto, A.; Altermatt, F. Complex interaction of dendritic connectivity and hierarchical patch size on biodiversity in river-like landscapes. Am. Nat. 2014, 183, 13-25. [CrossRef] [PubMed]

55. Kociolek, J.P.; Stoermer, E.F. Oligotrophy: The forgotten end of an ecological spectrum. Acta Bot. Croat. 2009, $68,465-472$.

(C) 2017 by the authors. Licensee MDPI, Basel, Switzerland. This article is an open access article distributed under the terms and conditions of the Creative Commons Attribution (CC BY) license (http://creativecommons.org/licenses/by/4.0/). 